\title{
The B-adrenoceptor antagonist, propranolol, induces human gastric cancer cell apoptosis and cell cycle arrest via inhibiting nuclear factor $\mathrm{KB}$ signaling
}

\author{
XINHUA LIAO, XIANGMING CHE, WEI ZHAO, DANJIE ZHANG，TIEQIANG BI and GUANGHUI WANG
}

Department of General Surgery, First Affiliated Hospital of Medical College of Xi'an JiaoTong University, Xi'an 710061, P.R. China

Received July 9, 2010; Accepted August 24, 2010

DOI: $10.3892 /$ or_00001032

\begin{abstract}
In a recent clinical observation, the growth of endothelial tumors, such as nasopharyngeal carcinoma, was repressed by the non-selective-adrenergic antagonist propranolol. In this study, we evaluated whether $\beta$-adrenoceptors (B-ARs), nuclear factor $\kappa \mathrm{B}(\mathrm{NF}-\kappa \mathrm{B})$, vascular endothelial growth factor (VEGF), cyclooxygenase-2 (COX-2), matrix metallo-proteinase-2 (MMP-2) and matrix metalloproteinase-9 (MMP-9) were involved in modulating cell apoptosis and cell cycle arrest by propranolol in human gastric adenocarcinoma cell lines (SGC-7901 and BGC-823) in vitro. Our results showed that the propranolol treatment inhibited cell proliferation in a concentration-dependent manner, suggesting the involvement of B-ARs in this cellular response. Propranolol-induced growth inhibition was associated with G0/G1 arrest and G2/M arrest depending upon the concentration. In addition, propranolol also induced apoptosis in both cell lines, as determined by Annexin V staining assay. Furthermore, propranolol decreased the level of NF- $\kappa \mathrm{B}$ and then downregulated VEGF, Cox-2, MMP-2 and MMP-9 expression. Collectively, these results suggested that propranolol repressed gastric cancer cell growth through the inhibition of $\mathrm{B}-\mathrm{ARs}$ and the downstream NF- $\mathrm{BB}-\mathrm{VEGF} /$ MMP-2/9/COX-2 pathway.
\end{abstract}

\section{Introduction}

Gastric cancer accounts for about $10 \%$ of invasive cancers worldwide, and it is the second leading death-causing cancer. Though the incidence of gastric cancer has been decreasing, it remains a common malignancy worldwide, especially in

Correspondence to: Professor Xiangming Che, Department of General Surgery, First Affiliated Hospital of Medical College of Xi'an JiaoTong University, Yanta West Road 277, Xi'an 710061, P.R. China

E-mail: chexiang@mail.xjtu.edu.cn

Key words: propranolol, gastric cancer, $\beta$-adrenergic receptor, nuclear factor $\mathrm{\kappa B}$
Asia (1). Several factors are strongly correlated with the increased risk of gastric cancer, including diet, genetic factors, environmental factors, infectious agents and pathological condition in the stomach (2). An imbalance in stimulatory and inhibitory neurotransmission can explain the factors mentioned above. The neurotransmitters acetylcholine, adrenaline and noradrenaline of the autonomic nervous system act as powerful upstream regulators. They modulate numerous cell and tissue functions by releasing growth factors, angiogenesis factors, metastasis factors, arachidonic acid, proinflammatory cytokines and local neurotransmitters from cancer cells and their microenvironment.

In addition, they directly modulate proliferation, apoptosis, angiogenesis and metastasis of cancer by intracellular signaling of downstream neurotransmitter receptors. It has been reported that $\beta$-adrenoreceptors ( $\beta$-ARs) expressed in cancer of the esophageal, breast, nasopharynx, pancreas and colon cell lines is the key factor, which induces tumor formation due to long-term smoking and chronic stress (3-7). Neurotransmitters, which act through adrenoceptors, control the tissue proliferation by modulating diverse intracellular processes. The subtypes of $B-A R$ have been classified as $\beta_{1^{-}}, \beta_{2^{-}}$and $\beta_{3^{-}}$-ARs. Shin et al reported that 4-(methylnitrosamino)-1-(3-pyridyl)1-butanone (NNK, which was extracted from cigarettes, acts as a $ß$-adrenergic receptor agonist) enhances cell proliferation in gastric cancer cells (8).

In this study, we evaluated the expression of $\beta-A R s$ in two gastric cell lines (SGC-7901 and BGC-823). We also studied the effect of isoproterenol ( $\beta$-adrenergic receptor agonist) and propranolol ( $\beta$-adrenergic receptor antagonist). We hypothesized that the $\beta$-adrenergic receptor antagonist could suppress the proliferation of gastric cancer cells via induction of cell cycle arrest and apoptosis. Therefore, we examined cell cycle and cell apoptosis by flow cytometry (FCM), and cell proliferation by MTT assay. Finally, we evaluated nuclear factor $\kappa \mathrm{B}(\mathrm{NF}-\kappa \mathrm{B})$ and downstream factors in the signal pathway using real-time RT-PCR and Western blotting.

\section{Materials and methods}

Cell culture and drug treatment. The human gastric adenocarcinoma (HGC) cell line (BGC-823) and HGC cell line (SGC-7901) were established in People's Hospital of Peking 
Table I. The primer sequences and annealing temperatures for the seven investigated genes.

\begin{tabular}{|c|c|c|c|c|}
\hline Gene & $\begin{array}{c}\text { Annealing } \\
\text { temperature }\left({ }^{\circ} \mathrm{C}\right)\end{array}$ & Prime sequence & $\begin{array}{l}\text { Amplicon } \\
\text { (bp) }\end{array}$ & Accession no. \\
\hline$\beta$-actin & 60 & $\begin{array}{l}\text { Forward: ATCGTGCGTGACATTAAGGAGAAG } \\
\text { Reverse: AGGAAGGAAGGCTGGAAGAGTG }\end{array}$ & 179 & NM_001101 \\
\hline$\beta_{1}-A R$ & 60 & $\begin{array}{l}\text { Forward: GGGAGAAGCATTAGGAGGG } \\
\text { Reverse: CAAGGAAAGCAAGGTGGG }\end{array}$ & 270 & NM_000684 \\
\hline$\beta_{2}-A R$ & 60 & $\begin{array}{l}\text { Forward: CAGCAAAGGGACGAGGTG } \\
\text { Reverse: AAGTAATGGCAAAGTAGCG }\end{array}$ & 334 & NM_000024 \\
\hline$C O X-2$ & 57 & $\begin{array}{l}\text { Forward: TTGACCAGAGCAGGCAGATG } \\
\text { Reverse: CCAGAAGGGCAGGATACAGC }\end{array}$ & 171 & NM_000963.2 \\
\hline$V E G F-A$ & 57 & 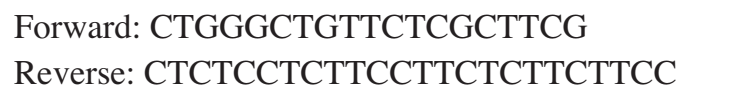 & 140 & NM_001025370.1 \\
\hline$M M P-2$ & 53 & $\begin{array}{l}\text { Forward: CCGTCGCCCATCATCAAGTTC } \\
\text { Reverse: GCAGCCATAGAAGGTGTTCAGG }\end{array}$ & 90 & NM_001127891 \\
\hline$M M P-9$ & 60 & $\begin{array}{l}\text { Forward: TGGTCCTGGTGCTCCTGGTG } \\
\text { Reverse: GCTGCCTGTCGGTGAGATTGG }\end{array}$ & 111 & NM_004994.2 \\
\hline
\end{tabular}

University, China and No. 6 Hospital of Shanghai, China, respectively. These two human gastric cancer cell lines were obtained from the Medical Center Laboratory of Xi'an Jiaotong University (Xi'an, China). Both cell lines were cultured in complete Dulbecco's modified Eagle's medium (Gibco, Grand Island, NY) containing $10 \%(\mathrm{v} / \mathrm{v})$ heat-inactivated fetal bovine serum (Gibco), penicillin $(100 \mathrm{U} / \mathrm{ml})$ and streptomycin $(100 \mathrm{mg} / \mathrm{ml})$, which were maintained in a $37^{\circ} \mathrm{C}$ humidified incubator supplying with $5 \% \mathrm{CO}_{2}$. When cells reached the logarithmic phase, they were treated with isoproterenol or propranolol at different concentrations. The B-AR antagonist propranolol and $B$-AR excitomotor isoproterenol, were purchased from Sigma Chemical (St. Louis, MO, USA).

Cell viability. Cell viability was measured by the 3-(4,5dimethyl-thiazol-2-yl)-2,5-diphenyltetrazolium bromide (MTT) assay. MTT and dimethyl sulfoxide (DMSO) were obtained from Sigma Chemical. After incubation with isoproterenol or propranolol at different concentrations for $24 \mathrm{~h}$, cells were then incubated with $2.5 \%$ MTT solution $(5 \mathrm{mg} / \mathrm{ml})$ at $37^{\circ} \mathrm{C}$ for another $4 \mathrm{~h}$. Subsequently, $150 \mu \mathrm{l}$ of DMSO was added to solubilize the MTT tetrazolium crystals. Finally, the optical density was determined at $490 \mathrm{~nm}$ by a Benchmark Plus microplate reader (Bio-Rad, Hercules, CA). The tests were repeated in triplicate, and the mean optical density was calculated.

Cell cycle analysis. Cell cycle distribution was analyzed by FCM. Cells $\left(10^{5}\right)$ were treated with or without isoproterenol (10, 30 and $100 \mu \mathrm{mol} / \mathrm{l})$ or propranolol $(50,100$ and 200 $\mu \mathrm{mol} / \mathrm{l})$ at various concentrations for $24 \mathrm{~h}$. After the treatment, the cells were trypsinized and then centrifuged at $300 \mathrm{x} \mathrm{g}$ for $5 \mathrm{~min}$. Subsequently, cells were collected and washed with PBS 2 times. Then, cell pellets were resuspended in ice-cold $\mathrm{PBS}$ and fixed by $75 \%$ ethanol overnight. After washing with PBS, cell pellets were resuspended in $100 \mu \mathrm{g}$ RNase $\mathrm{A}$ and $20 \mu \mathrm{g}$ propidium iodide (PI), and incubated at $25^{\circ} \mathrm{C}$ for $30 \mathrm{~min}$ in the dark. DNA distribution was analyzed by FCM (BD Biosciences, USA).

Cell apoptosis analysis. In order to detect phosphatidylserine externalization (on the surface of cell membrane), an endpoint indicator of early apoptosis, FCM was performed with PI and fluorescein isothiocyanate (FITC)-labeled annexin V (Joincare Biosciences, Zhuhai, China). After the treatment, the remaining intact cells were incubated at $37^{\circ} \mathrm{C}$ for $24 \mathrm{~h}$, and then the cells were washed with cool PBS at $4^{\circ} \mathrm{C}$. After a centrifugation at $1500 \mathrm{rpm}$ for $5 \mathrm{~min}, 500 \mu \mathrm{l}$ of $1 \mathrm{X}$ Binding buffer, $5 \mu 1$ of FITC-labeled Annexin V and $10 \mu 1$ of PI were added to the cell suspension and gently mixed. After incubation at $25^{\circ} \mathrm{C}$ for $10 \mathrm{~min}$ in the dark, the cells were analyzed by FCM.

Real-time reverse transcription polymerase chain reaction (real-time RT-PCR). Total RNA was extracted from cultured cells by Tri-Reagent. In order to eliminate DNA contamination, extracted RNA was treated with genomic DNA elimination mixture. Subsequently, the purified RNA was reversely transcribed to cDNA. $\beta_{1}$ - and $\beta_{2}$-ARs were identified by RT-PCR (Applied Biosystems, Inc., Foster City, CA). The gene expression of Cox-2, VEGF, MMP-2 and MMP-9 was quantified by real-time PCR kit from Takara (Takara Biochemicals, Japan). Briefly, following a preheating program at $95^{\circ} \mathrm{C}$ for $10 \mathrm{~min}$, the reaction was carried out by an Icycler (Bio-Rad) at a melting temperature of $95^{\circ} \mathrm{C}$ for $15 \mathrm{sec}$, an annealing temperature for $1 \mathrm{~min}$ for 40 cycles. Table I shows the primer sequences and annealing temperatures 

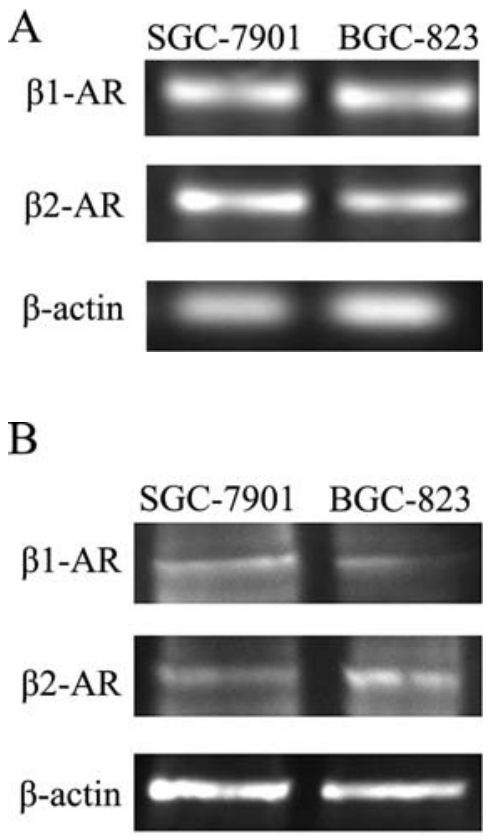

Figure 1. Expression of ARs of human gastric cell lines SGC-7901 and BGC-823 by RT-PCR (A). Both cell lines expressed $\beta_{1}$ - and $\beta_{2}$-ARs mRNA. Expression of B-ARs of human gastric cell lines SGC-7901 and BGC-823 at the protein level by Western blotting (B). Both cell lines expressed the proteins of $\beta_{1}$ - and $\beta_{2}$-ARs.

of the seven investigated genes. Primers were designed according to Genbank, NCBI. For the validation, each experiment was done in triplicate.

Western blot assay. The primary antibodies of $\beta_{1^{-}}$and $\beta_{2^{-}}$ adrenergic receptors were purchased from Abcam (Cambridge, MA). Antibodies of Cox-2, VEGF, NF-кB (p65), MMP-2 and MMP-9 were purchased from Santa Cruz Biotechnology (Santa Cruz, CA). The nitrocellulose membrane was purchased from Millipore (Bedford, MA). The BCA assay kit and the chemiluminescence kit were purchased from Pierce (Rockford, IL). Briefly, $20 \mathrm{mg}$ of each sample, quantified by Bradford method, were electrophoresed on 10\% SDS-PAGE and electrotransferred onto nitrocellulose membrane (400 mA for $2 \mathrm{~h}$ ) by Bio-Rad Mini Protean 3 System (Hercules, CA) according to the standard protocol. The nitrocellulose membranes were then blocked with TBS containing $10 \%$ milk powder and $0.1 \%$ Tween-20 at $37^{\circ} \mathrm{C}$ for $4 \mathrm{~h}$. Subsequently, the membranes were incubated with $1: 200$ of the primary antibodies of $\beta_{1}$-AR, $\beta_{2}$-AR, Cox-2, VEGF, MMP-2, MMP-9 and NF-кB (p65), 1:500 of anti- $\beta$-actin at $4{ }^{\circ} \mathrm{C}$ overnight, respectively. The antibody against rabbit or mouse $\operatorname{IgG}$ was adopted as the secondary antibody corresponding to the primary antibody. Peroxidase activity was visualized with the chemiluminescence kit according to the manufacturer's instructions.

Statistical analysis. The results were expressed as mean \pm SD. Statistical differences were estimated by One-way analysis of variance (ANOVA) followed by Dunnett's test. $\mathrm{P}<0.05$ was considered statistically significant. Analysis of the data and plotting of the figures were performed with the aid of software (SPSS version 13.0).
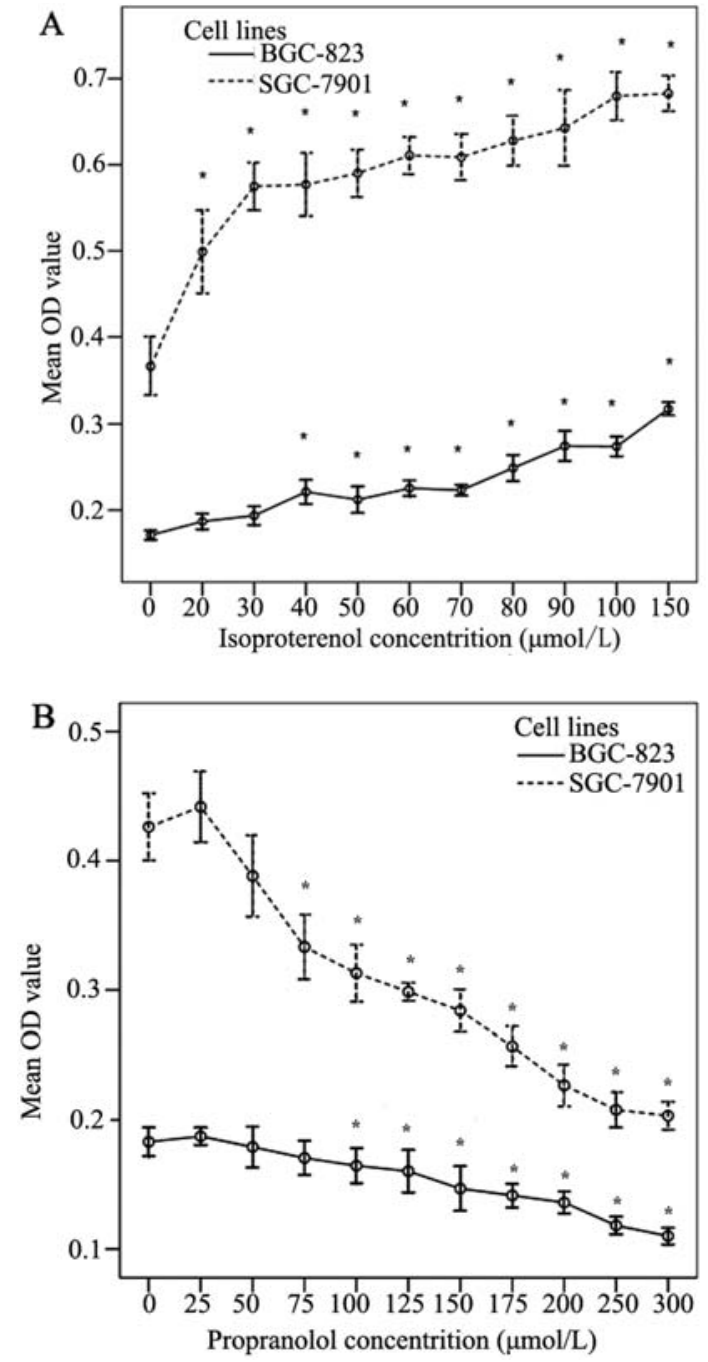

Figure 2. MTT assay showed that BGC-823 cells (solid line) and SGC-7901 cells (dash line) treated with isoproterenol for $24 \mathrm{~h}$ could increase cellular proliferation in a concentration-dependent manner (A). Propranolol inhibited the proliferation of BGC-823 cells and SGC-7901 cells in a concentrationdependent manner (B).

\section{Results}

Expression of $\beta_{1}, \beta_{2}$-adrenergic receptors at the $m R N A$ and protein level in SGC-7901 and BGC-823 cells. Since propranolol is a $\beta$-adrenergic receptor antagonist, the expression of $\beta_{1}, \beta_{2}$-ARs was determined at the mRNA and protein levels in SGC-7901 and BGC-823 cells by real-time RT-PCR and Western blotting, respectively. Our results showed that $B_{1}$, $\beta_{2}$-adrenergic receptors could be detected at the mRNA and protein levels in both cell types. Fig. 1 shows that the expression of $\beta_{1}, \beta_{2}$-adrenergic receptors in SGC-7901 cells was higher than that in BGC-823 cells.

The $\beta$-adrenergic receptor antagonist propranolol inhibits gastric cancer proliferation while isoproterenol, a $\beta$-adrenergic receptor agonist, shows the opposite effect. We used MTT assay to assess cell proliferation in SGC-7901 and BGC-823 cells treated with propranolol or isoproterenol. Fig. 2 shows that the induced cell proliferation was dose-dependent after the treatment of propranolol or isoproterenol at different 
A

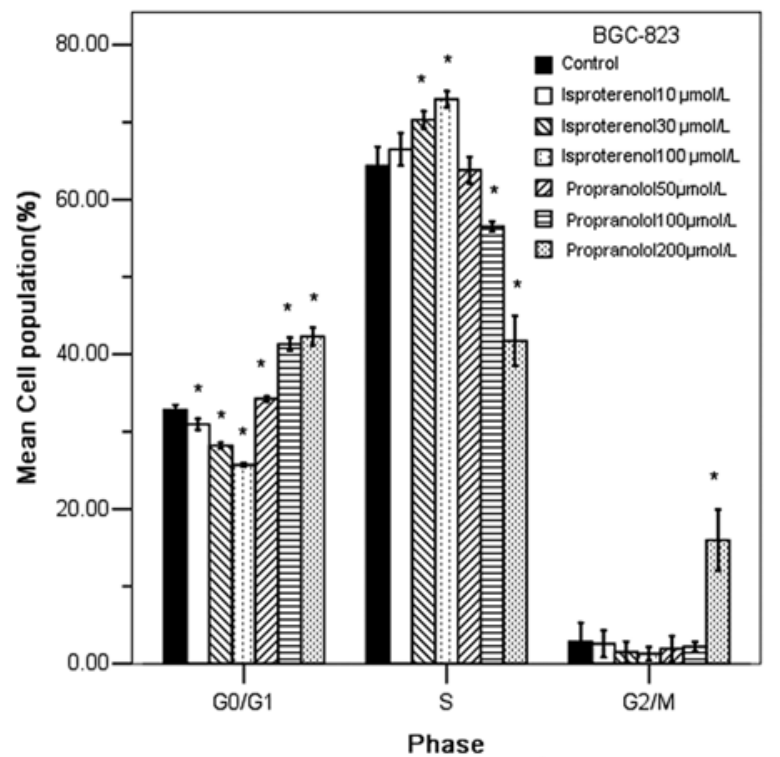

B

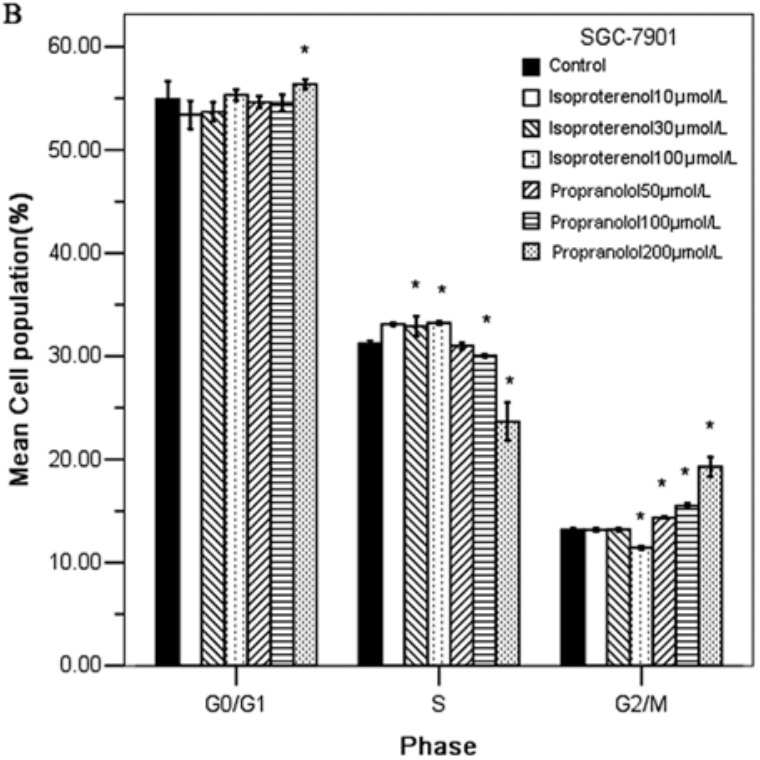

Figure 3. Effects of isoproterenol or propranolol on the progression of cell cycle in BGC-823 (A) and SGC-7901 (B) cells. The distribution of cell population was expressed as the percentage of cells counted in BGC-823 and SGC-7901 cultures treated for 24 h. Each value represented as mean \pm SE of three independent experiments. ${ }^{*} \mathrm{P}<0.05$ was considered as statistically significant with ANOVA followed by Dunnett's test.
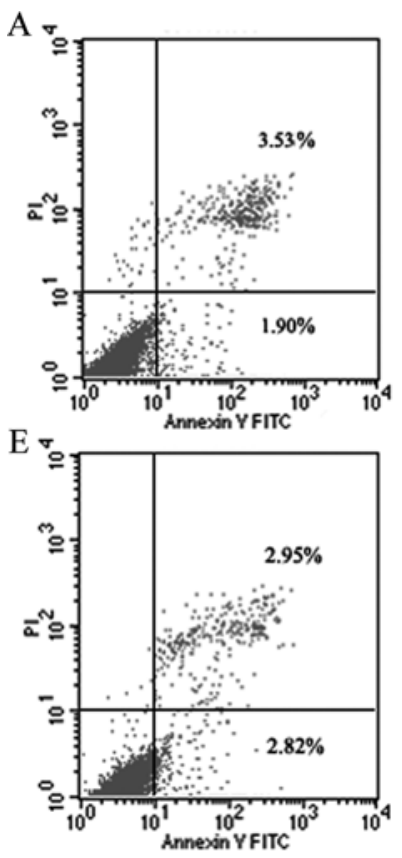
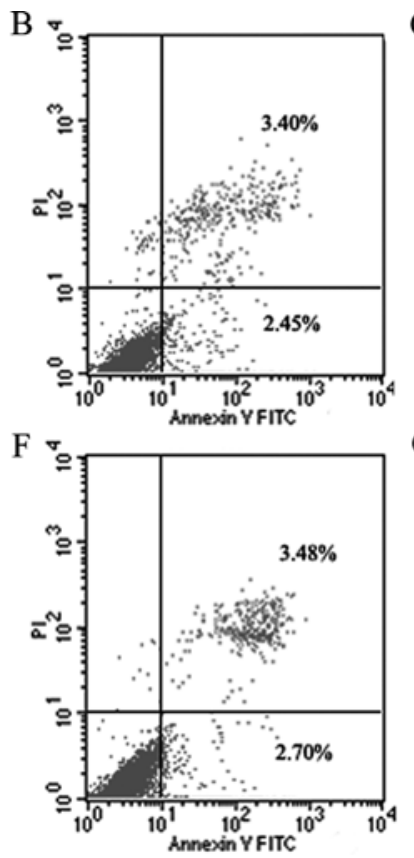
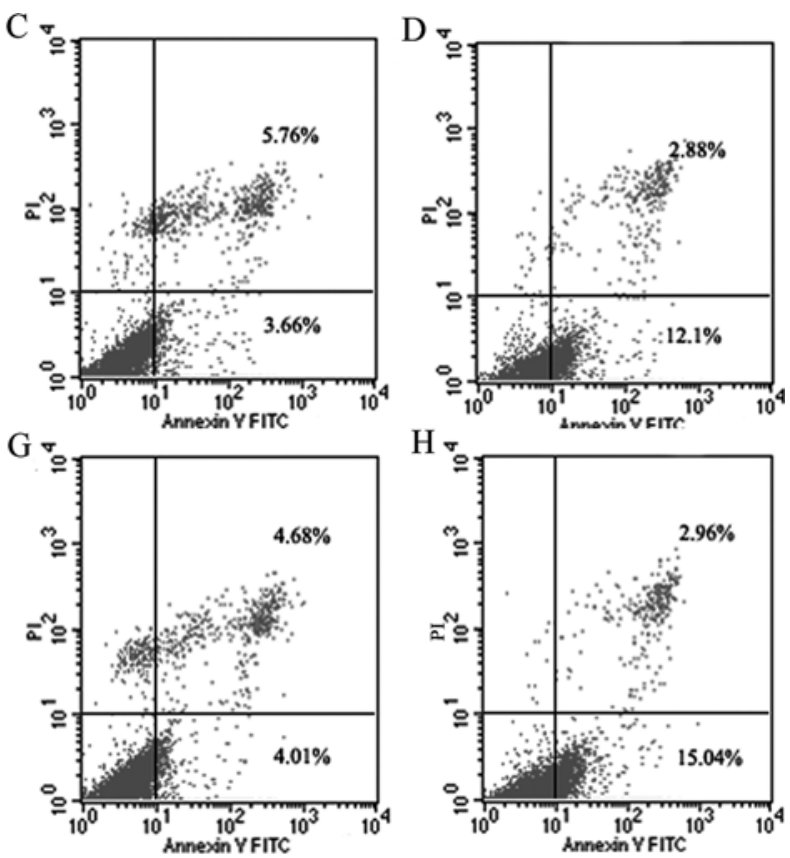

Figure 4. Apoptotic BGC-823 cells after treatment with isoproterenol at $0 \mathrm{mmol} / \mathrm{l}$ (A), $10 \mathrm{mmol} / 1$ (B), $30 \mathrm{mmol} / 1$ (C), $100 \mathrm{mmol} / \mathrm{l}$ (D) and propranolol at $0 \mathrm{mmol} / \mathrm{l}(\mathrm{E}), 50 \mathrm{mmol} / \mathrm{l}(\mathrm{F}), 100 \mathrm{mmol} / \mathrm{l}(\mathrm{G}), 200 \mathrm{mmol} / \mathrm{l}(\mathrm{H})$ for SGC-7901 cells detected by FCM. Significant apoptosis was induced by propranolol in a concentration-dependent manner on both BGC-823 and SGC-7901 cells.

concentrations for $24 \mathrm{~h}$. We found that $200 \mu \mathrm{M}$ of propranolol inhibited cell proliferation in SGC-7901 cells compared with the controls, ranging from $0.23 \pm 0.016$ to $0.43 \pm 0.026(\mathrm{P}=0.001)$. BGC-823 cells showed a relatively weaker concentration-dependent inhibition effect, ranging from $0.14 \pm 0.083$ to $0.18 \pm 0.011(\mathrm{P}=0.001)$. Furthermore, the cell proliferation was promoted in SGC-7901 cells treated with $100 \mu \mathrm{M}$ of compared with the controls $(0.68 \pm 0.28$ vs. $0.37 \pm 0.034, \mathrm{P}=0.001)$, and it was $0.27 \pm 0.011$ vs. $0.17 \pm 0.053$ $(\mathrm{P}=0.001)$ in BGC-823 cells.
Propranolol induces G0/G1 and G2/M phase cell cycle arrest in gastric cancer cells. In order to study the mechanism of propranolol inhibition on cell proliferation, we performed cell cycle analysis in the propranolol-treated gastric cancer cells as shown in Fig. 3. Exposure of BGC-823 cells to propranolol/isoproterenol resulted in the enrichment/reduction of $\mathrm{G} 0 / \mathrm{G} 1$ phase $(\mathrm{P}<0.05$ vs. control), accompanying with a decrease/increase in $\mathrm{S}$ phase. However, BGC-823 cells only exposed to $200 \mu \mathrm{M}$ propranolol showed an increase of $\mathrm{G} 2 / \mathrm{M}$ cell population $(\mathrm{P}=0.01)$ compared with the controls. 
A

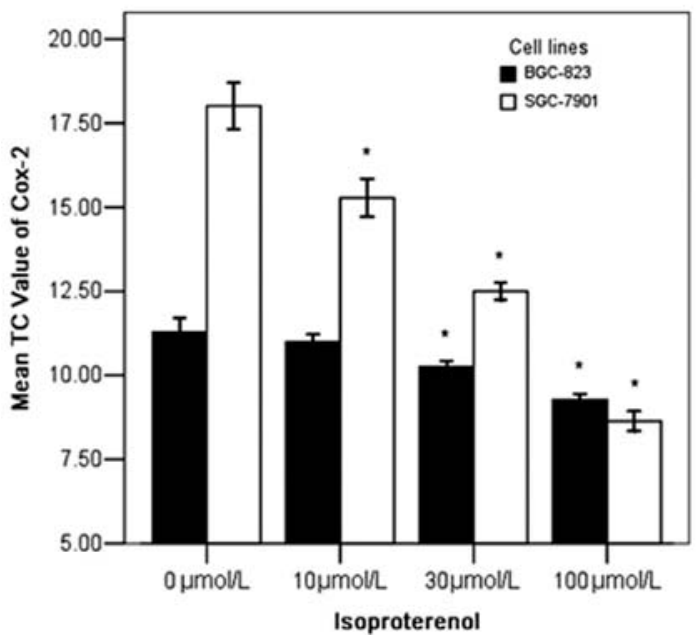

B

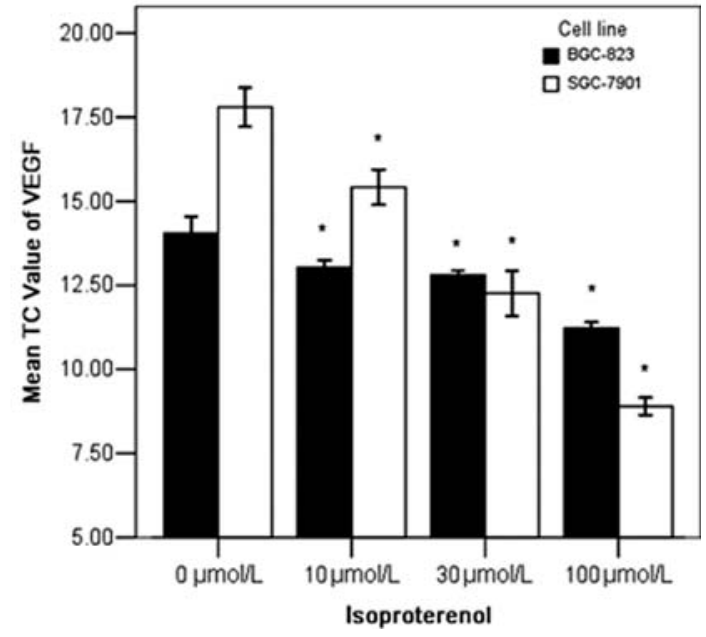

D

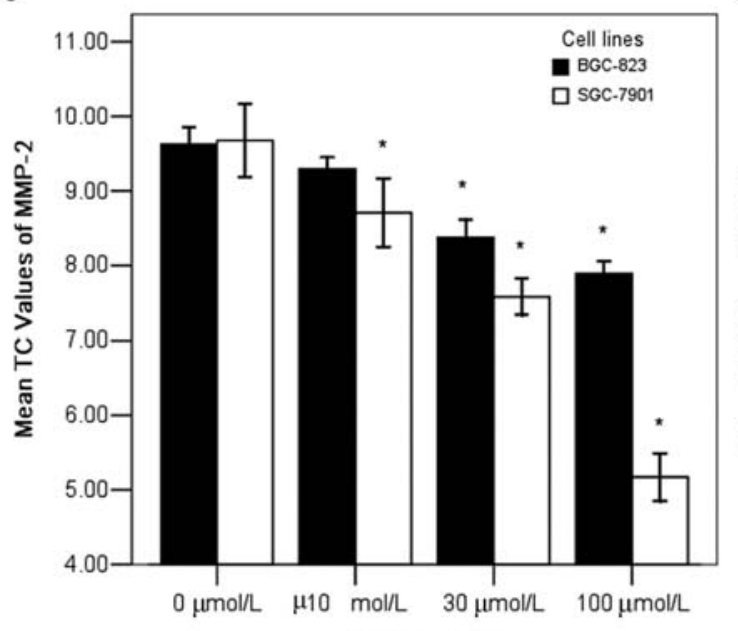

Isoproterenol

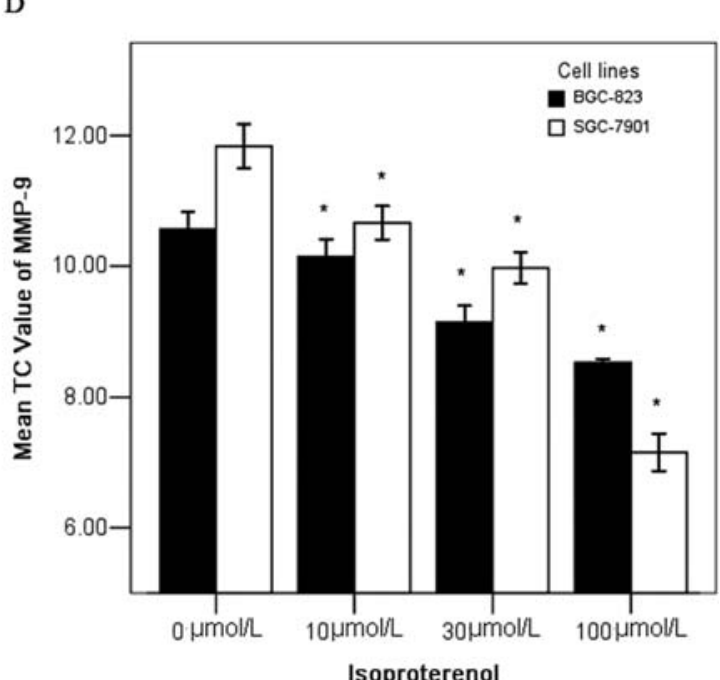

Isoproterenol

Figure 5. Quantification of expression of Cox-2, VEGF, MMP-2 and MMP-9 at the mRNA level in SGC-7901 (A-D) and BGC-823 (E-H) cells was performed on different concentrations and different drugs by iCycler (Bio-Rad). The overexpression/low expression of Cox-2, VEGF, MMP-2 and MMP-9 genes was changed by isoproteronol/propranolol in a concentration-dependent manner. ${ }^{*} \mathrm{P}<0.05$ versus the control goup or the group without the drugs.

Furthermore, propranolol-treated SGC-7901 cells showed the enrichment of $\mathrm{G} 2 / \mathrm{M}$ phase, accompanying with a decrease in $\mathrm{S}$ phase. While SGC-7901 cells only exposed to $200 \mu \mathrm{M}$ propranolol showed an increase of G0/G1 cell population in comparison with the controls. However, SGC-7901 cells exposed to isoproterenol showed very slight increase of S-phase cell population in comparison with the controls. These results indicated that propranolol was able to induce cell cycle arrest in $\mathrm{G} 0 / \mathrm{G} 1$ or G2/M phase before cell death in SGC-7901 and BGC-823 cells. Similar to propranolol, the treatment of isoproterenol resulted in the same effects of $\mathrm{G} 0 / \mathrm{G} 1$ or $\mathrm{G} 2 / \mathrm{M}$ phase enrichment. These data suggested that propranolol inhibited the proliferation of gastric cancer cells by inhibiting cell cycle progression, while isoproterenol demonstrated the opposite effect.

Propranolol induces gastric cancer apoptosis in vitro. In addition to cell cycle arrest, the growth inhibition induced by propranolol could also be due to the programmed cell death. Therefore, we investigated whether propranolol induced cell apoptosis. Fig. 4 shows that following the propranolol treatment (1-200 $\mu \mathrm{M}$ for $24 \mathrm{~h})$, FCM demonstrated a dosedependant increase in Annexin-FITC positive apoptotic BGC-823 (apoptosis rate from 0 to $200 \mu \mathrm{M}: 4.13 \pm 0.40 \%$, $5.59 \pm 0.55 \%, 7.52 \pm 0.23 \%, 15.19 \pm 2.0 \%$; $\mathrm{P}<0.05$ vs. control) and SGC-7901 cells $(5.75 \pm 0.17 \%, 6.14 \pm 0.23 \%, 8.50 \pm 0.95 \%$, $18.15 \pm 2.4 \%$; $\mathrm{P}<0.05$ vs. control). These data suggested that propranolol could induce gastric cancer cell apoptosis in a dose-dependent manner.

Determining the roles of $\beta$-adrenergic receptors and downstream signaling factors. We evaluated whether B-ARs mediated the propranolol/isoproterenol-dependent modulation of NF-кB expression at the mRNA (Fig. 5) and protein levels (Fig. 6) and then influenced the downstream expression of COX-2, VEGF, MMP-2 and MMP-9 in BGC-823 and SGC7901 cells. We treated the cells with nonselective $B-A R$ antagonist (propranolol 0, 50, 100, 200 $\mu \mathrm{M}$ ) and agonist (isoproterenol $0,10,30,100 \mu \mathrm{M}$ ) at different concentrations for $24 \mathrm{~h}$. With real-time RT-PCR and Western blot assay, we found that the NF- $\mathrm{B}$ (p65) expression at the protein level was downregulated in the propranolol-treated BGC-823 and 
$\mathrm{E}$
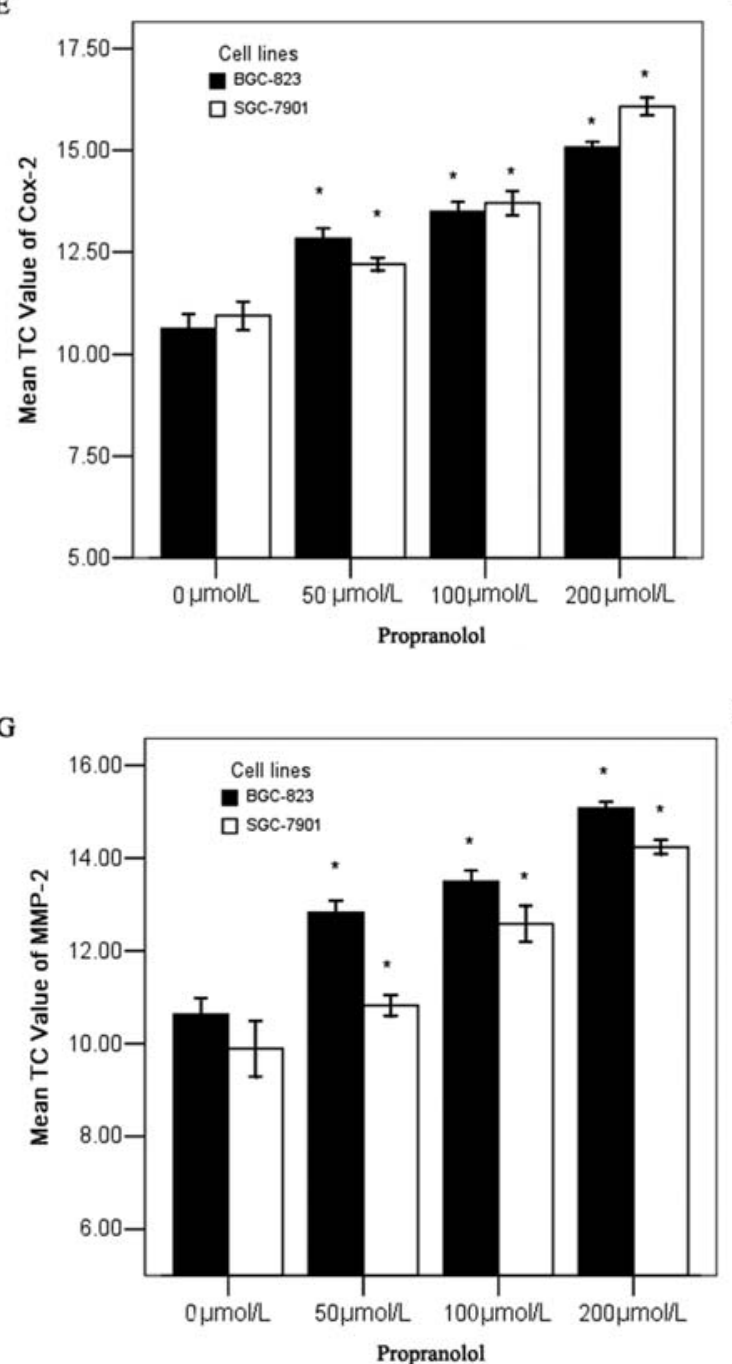

F

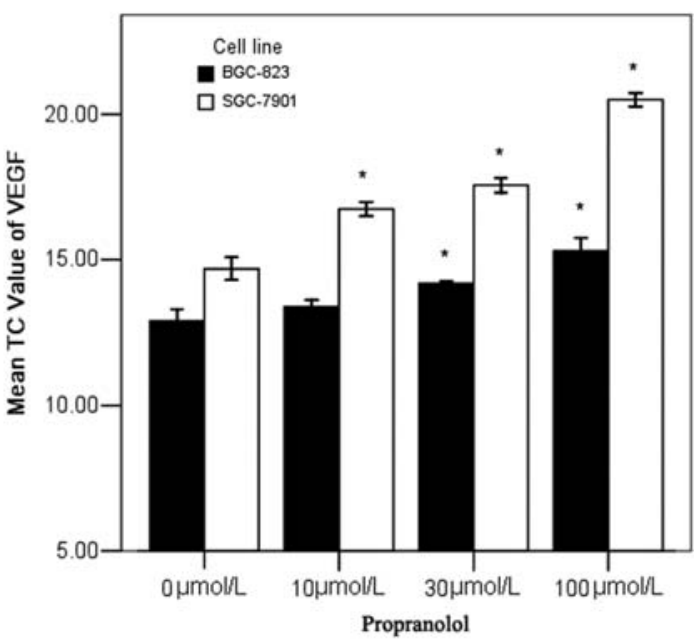

$\mathrm{H}$

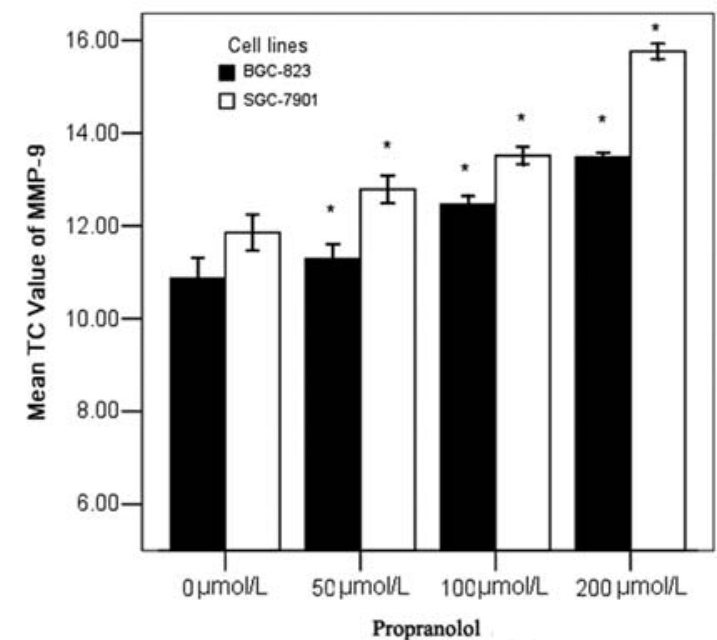

Figure 5. Continued.

SGC-7901 cells, accompanying with the decreased expression of COX-2, VEGF, MMP-2 and MMP-9 at the protein level. This is consistent with the decreased expression of COX-2, VEGF, MMP-2 and MMP-9 at the mRNA level after the propranolol treatment. The expression of these genes at the mRNA and protein levels was a dose-dependent in propranolol-treated BGC-823 and SGC-7901 cells.

In contrast to propranolol, the expression of NF- $\kappa \mathrm{B}$ (p65), COX-2, VEGF, MMP-2 and MMP-9 at the protein level was upregulated by isoproterenol treatment in gastric cancer cells, and this was consistent with the increased expression of COX-2, VEGF, MMP-2 and MMP-9 at the mRNA level in a dose-dependent manner after the isoproterenol treatment. These results clearly suggested that the propranolol-dependent downregulation of COX-2, VEGF, MMP-2 and MMP-9 in gastric cancer cells was mainly due to the decreased expression of $N F-\kappa B$ via inhibition of $B-A R s$.

\section{Discussion}

Gastric cancer is one of the major cancers with high mortalities in the world. Several factors like smoking, drinking, stress and drugs strongly correlate with the increased risk of gastric cancer. They play key roles in cancer cell proliferation, metastasis and invasion. Evidence has come to light elucidating the regulatory role of neurotransmitters in the regulation of tumor cells (9). The neurotransmitters acetylcholine, adrenaline and noradrenaline of the autonomic nervous system act as powerful upstream regulators by releasing growth factors, angiogenesis factors, metastasis factors, arachidonic acid, proinflammatory cytokines and local neurotransmitters from cancer cells and their microenvironment.

In addition, they directly modulate proliferation, apoptosis, angiogenesis and metastasis of cancer cells by intracellular signaling of downstream neurotransmitter receptors. Some neurotransmitters, which act through $\beta_{1^{-}}, \beta_{2}$-ARs, control the tissue proliferation by modulating diverse intracellular processes. NNK, an important B-AR agonist in cigarette smoke, is formed by nitrosation of nicotine, and it is a strong chemical that causes lung cancer among smokers (10). Propranolol, a non-selective $\beta$-adrenergic antagonist, has been widely used in clinic under various conditions, including hypertension, anxiety and excessive sympathetic responses, which often characterize patients during the perioperative period (11). It can inhibit the proliferation of nasopharyngeal carcinoma cells (12). 
A

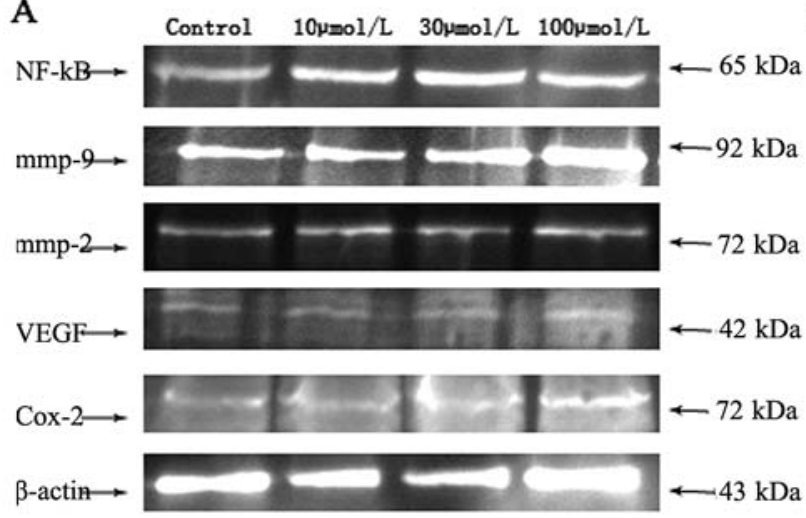

B

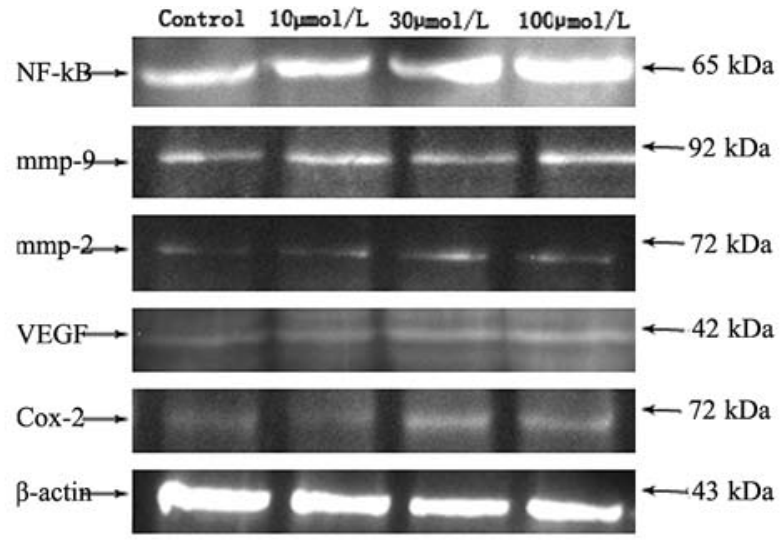

$\mathrm{C}$

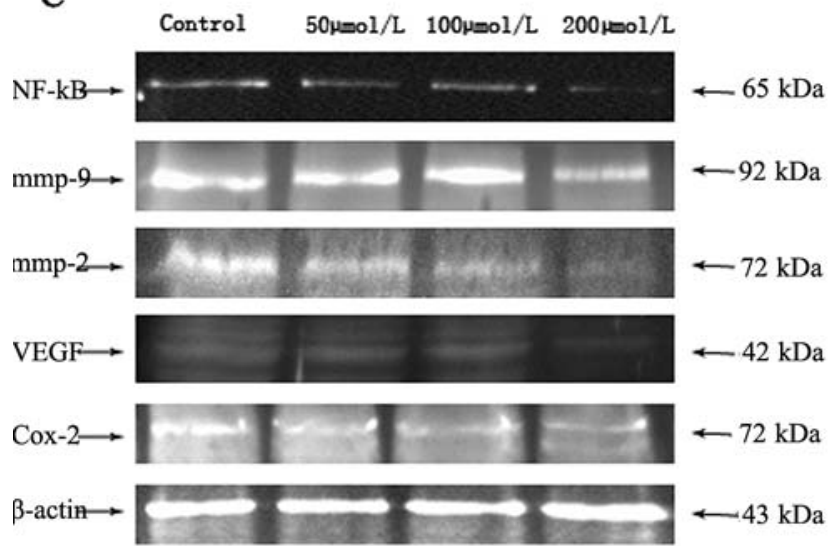

D

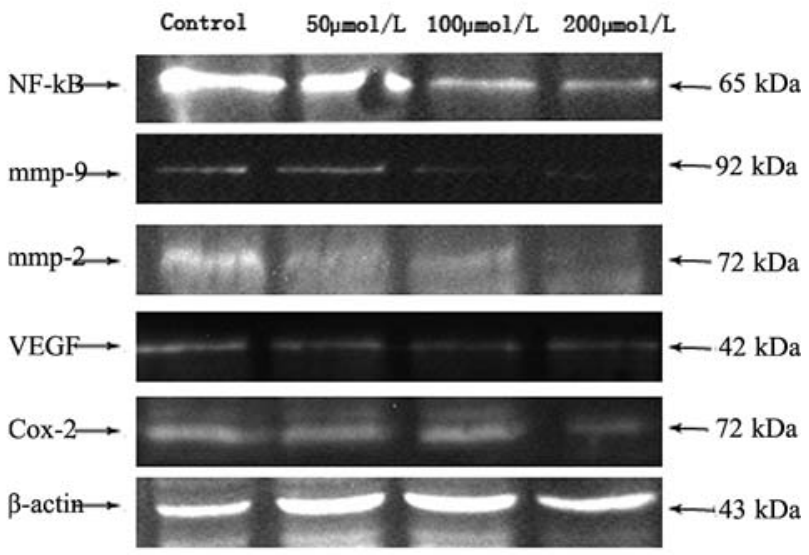

Figure 6. Effects of isoproterenol or propranolol on Cox-2, VEGF, MMP-2, MMP-9 and NF-kB (p65) at the protein level. SGC-7901 (A) and BGC-823 (B) cells were treated with isoproterenol $(0,10,30$ and $100 \mu \mathrm{mol} / 1)$ for $24 \mathrm{~h}$. SGC-7901(C) and BGC-823(D) cells were treated with propranolol (0, 50, 100 and $200 \mu \mathrm{mol} / \mathrm{l}) 24 \mathrm{~h}$. The protein levels on Cox-2, VEGF, MMP-2, MMP-9, and NF-кB (p65) were analyzed by Western blotting.

In our study, both of the gastric cancer cell lines (BGC823 and SGC-7901) expressed $\beta_{1}, \beta_{2}$-ARs. Therefore, neurotransmitters could act as a regulator through $\beta$-ARs. Fig. 2 shows that the two important agonist and antagonist, isoproterenol and propranolol, exhibited a concentrationdependent growth-facilitative/inhibitory effect on gastric cancer cell lines by activating or inhibiting the $\beta$-adrenergic receptor. Control of cell cycle progression in cancer cells is considered to be a potentially effective strategy in tumor treatment (13).

Fig. 3 shows that the inhibition of cell growth observed in propranolol-treated cells was apparently due to the induction of G0/G1 cell cycle arrest in BGC-823 cells and G2/M cell cycle arrest in SGC-7901 cells. The B-AR agonist, isoproterenol, showed the opposite effect on cell cycle. G1 phase arrest in cell cycle progression provides an opportunity for cells to either undergo repair mechanisms or follow the apoptotic pathway. Defects in the G1 arrest checkpoint may enhance cancer cell proliferation, and efforts to correct these problems may impede cell growth and induce cell death. Defects in the G2-M arrest checkpoint may allow a damaged cell to enter mitosis and undergo apoptosis, and efforts to enhance this effect may increase the cytotoxicity of chemotherapy. Alternatively, efforts to increase G2-M arrest have also been associated with the enhanced apoptosis (14). With FCM analysis, Fig. 4 shows that propranolol might induce apoptosis in a dose-dependent manner via B-AR pathways in SGC-7901 and BGC-823 cells.

It has been shown that $\mathrm{NF}-\kappa \mathrm{B}$ is involved in modulating the expression of several proinflammatory, prometastatic and proangiogenic genes, including Cox-2, MMPs and VEGF $(15,16)$. Since NF-кB plays important roles in many cellular processes, recent studies have been focused on the interaction of NF- $\kappa \mathrm{B}$ activation with other cell signal transduction pathways, including the $\beta$-AR pathway. The activation of $\mathrm{NF}-\kappa \mathrm{B}$ p50 homodimers in nasopharyngeal carcinoma occurs independently of LMP-1 (EBvirus gene) expression. Bierhaus et al showed that norepinephrine ( $ß$-AR agonist) can activate $\mathrm{NF}-\kappa \mathrm{B}$ when it binds to $\beta-A R s$ (17). Activation of $\mathrm{NF}-\kappa \mathrm{B}$ leads to the upregulation of several downstream target genes, including Cox-2, MMPs and VEGF. Therefore, it is possible that $\mathrm{B}$-AR-induced cell proliferation and invasion is partly due to the activation of NF- $\mathrm{KB}$ pathway. Cox-2 has been linked to cancers, suggesting that another pathway whereby inflammation can be a co-factor for modulating tumor cell growth.

The stimulation of $\beta$-ARs has been linked to the arachidonic acid cascade, especially Cox -2 expression, in various types of cancer $(6,18)$. Cox- 2 is aberrantly overexpressed in colon cancer and plays an essential role in 
cancer progression (19). The MMPs are a family of related enzymes that degrade extracellular matrix, which are considered to be important factors in facilitating tumor invasion. Among these MMPs, MMP-9 and MMP-2 have been considered to be two important factors in facilitating invasion and metastases in pancreatic cancer (20). Moreover, VEGF, the most well-characterized angiogenic factor, is known to play a vital role in tumor-associated microvascular invasion $(21,22)$. In human gastric cancer, a higher expression of VEGF may be one explanation for the poorer prognosis (23). It is well accepted that NF- $\mathrm{KB}$ regulates the expression of MMP-2/9, VEGF and Cox-2 (24-26). In the present study, we found that propranolol, which acts via $B-A R$, reduced NF- $\kappa$ B DNA-binding activity and concomitantly inhibited the expression of Cox-2, MMP-2/9 and VEGF at the mRNA and protein levels. The inhibition of Cox-2, MMP-2/9 and VEGF expression by propranolol might be mediated by the inhibition of $\mathrm{NF}-\mathrm{\kappa B}$, in which the binding site has been found in the promoter of Cox-2, MMP-2/9 and VEGF. Thus, propranolol could partly potentiate the anti-inflammatory, antiproliferative and anti-metastasis activities by modulating $\mathrm{NF}-\kappa \mathrm{B}$ and downstream genes via $\beta$-ARs.

These findings along with the present experimental data strongly suggest that $\beta$-adrenergic receptor modulation plays an important role in the progression of gastric cancer. For the first time, our results demonstrate that $B$-adrenergic inhibition can block gastric cancer cell growth in vitro by downregulating NF- $\mathrm{KB}$ and modulating downstream MMP-2/9, Cox-2 and VEGF gene expression. Furthermore, we showed an opposite effect on isoproterenol administration. Certain behavior or drugs, such as smoking, chronic stress and B-AR agonist that can activate $B$-ARs, will accelerate the proliferation, invasion and metastasis of gastric cancer and lead to a poorer prognosis. These data suggest that blockade of B-AR-stimulated signal pathways could have therapeutic implications for the prevention and treatment of gastric cancer, especially in cigarette smokers and chronic stress patients.

\section{Acknowledgements}

The authors acknowledge Dr Dong Zhang of the Hepatobiliary Department of First Affiliated Hospital and the Institution of Genetic Disease Research and, Xi'an Jiaotong University for technical assistance.

\section{References}

1. Roder DM: The epidemiology of gastric cancer. Gastric Cancer 5: 5-11, 2002.

2. Tsugane $S$ and Sasazuki S: Diet and risk of gastric cancer: review of epidemiological evidence. Gastric Cancer 10: 75-83, 2007.

3. Liu X, Wu WK, Yu L, Li ZJ, Sung JJ, Zhang ST and Cho CH: Epidermal growth factor-induced esophageal cancer cell proliferation requires transactivation of $\beta$-adrenoceptors. J Pharmacol Exp Ther 326: 69-75, 2008.

4. Cakir Y, Plummer HK III, Tithof PK and Schuller HM: Badrenergic and arachidonic acid-mediated growth regulation of human breast cancer cell lines. Int J Oncol 21: 153-157, 2002.

5. Yang EV, Sood AK, Chen M, et al: Norepinephrine up-regulates the expression of vascular endothelial growth factor, matrix metalloproteinase (MMP)-2, and MMP-9 in nasopharyngeal carcinoma tumor cells. Cancer Res 66: 10358-10364, 2006.
6. Weddle DL, Tithoff P, Willians M and Schuller HM: $\beta-$ Adrenergic growth regulation of human cancer cell lines derived from pancreatic ductal caecinomas. Carcinogenesis 22: 473-479, 2001.

7. Wong HP, Yu L, Lam EK, Tai EK, Wu WK and Cho CH: Nicotine promotes colon tumor growth and angiogenesis through ß-adrenergic activation. Toxicol Sci 97: 279-287, 2007.

8. Shin VY, Jin HC, Ng EK, Yu J, Leung WK, Cho CH and Sung JJ: Nicotine and 4-(methylnitrosamino)-1-(3-pyridyl)-1-butanone induce cyclooxygenase- 2 activity in human gastric cancer cells: Involvement of nicotinic acetylcholine receptor (nAChR) and $\beta$-adrenergic receptor signaling pathways. Toxicol Appl Pharm 233: 254-261, 2008.

9. Entschladen F, Lang K, Drell TL, Joseph J and Zaenker KS: Neurotransmitters are regulators for the migration of tumor cells and leukocytes. Cancer Immunol Immunother 51: 467-482, 2002.

10. Schuller HM: Mechanisms of smoking-related lung and pancreatic adenocarcinoma development. Nat Rev Cancer 2: 455-463, 2002.

11. Emilien G and Maloteaux JM: Current therapeutic uses and potential of beta-adrenoceptor agonists and antagonists. Eur J Clin Pharmacol 53: 389-404, 1998.

12. Annabia B, Lachambreb M-P, Plouffeb K, Moumdjianc R and Béliveau R: Propranolol adrenergic blockade inhibits human brain endothelial cells tubulogenesis and matrix metalloproteinase-9 secretion. Pharmacol Res 60: 438-445, 2009.

13. Bruckheimer EM and Kyprianou N: Apoptosis in prostate carcinogenesis: a growth regulator and a therapeutic target: a review. Cell Tissue Res 301: 153-162, 2000.

14. DiPaola RS: To arrest or not to G2-M cell-cycle arrest. Clin Cancer Res 11: 3311-3314, 2002.

15. Dong Z, Bonfil RD, Chinni S, et al: Matrix metalloproteinase activity and osteoclasts in experimental prostate cancer bone metastasis tissue. Am J Pathol 166: 1173-1186, 2005.

16. Xiong HQ, Abbruzzese JL, Lin E, Wang L, Zheng L and Xie K: $\mathrm{NF}-\kappa \mathrm{B}$ activity blockade impairs the angiogenic potential of human pancreatic cancer cells. Int J Cancer 108: 181-188, 2004.

17. Bierhaus A, Wolf J, Andrassy M, et al: A mechanism converting psychosocial stress into mononuclear cell activation. Proc Natl Acad Sci USA 100: 1920-1925, 2003.

18. Randall EH, Bittman D, Dasgupta HE, et al: Cyclooxygenase 2 (COX-2) and the inflammogenesis of cancer. Subcellular Biochemistry 42: 93-126, 2007.

19. Castellone MD, Teramoto H, Williams BO, Druey KM and Gutkind JS: Prostaglandin $\mathrm{E}_{2}$ promotes colon cancer cell growth through a $\mathrm{G}_{\mathrm{s}}$-axin- $\beta$-catenin signaling axis. Science 310: 1504, 2005 .

20. Nagakawa Y, Aoki T, Kasuya K, Tsuchida A and Koyanagi Y: Histologic features of venous invasion, expression of vascular endothelial growth factor and matrix metalloproteinase 2 and matrix metalloproteinase 9, and the relation with liver metastasis in pancreatic cancer. Pancreas 24: 169-178, 2002.

21. Joo YE, Sohn YH, Lee WS, et al: Expression of vascular endothelial growth factor and p53 in pancreatic carcinomas. Korean J Intern Med 17: 153-159, 2002.

22. Zeng H, Datta K, Neid M, Li J, Parangi S and Mukhopadhyay D: Requirement of different signaling pathways mediated by insulin-like growth factor-I receptor for proliferation, invasion, and VPF/VEGF expression in a pancreatic carcinoma cell line. Biochem Biophys Res Commun 302: 46-55, 2003.

23. Shigeo K, Koji K, Hideki A, et al: Evaluation of VEGF and VEGF-C expression in gastric cancer cells producing $\alpha$-fetoprotein. J Gastroenterol 6: 540-547, 2003.

24. Sclabas GM, Uwagawa T, Schmidt C, et al: Nuclear factor $\kappa \mathrm{B}$ activation is a potential target for preventing pancreatic carcinoma by aspirin. Cancer 103: 2485-2490, 2005.

25. Takada Y, Kobayashi Y and Aggarwal BB: Evodiamine abolishes constitutive and inducible NF- $\mathrm{kB}$ activation by inhibiting $\operatorname{InB} \alpha$ kinase activation, thereby suppressing NF- $\mathrm{\kappa B}$-regulated antiapoptotic and metastatic gene expression, up-regulating apoptosis, and inhibiting invasion. J Biol Chem 280: 17203-17212, 2005.

26. Takada Y, Murakami A and Aggarwal BB: Zerumbone abolishes $\mathrm{NF}-\kappa \mathrm{B}$ and $\mathrm{InB} \alpha$ kinase activation leading to suppression of antiapoptotic and metastatic gene expression, upregulation of apoptosis, and downregulation of invasion. Oncogene 24: 6957-6969, 2005. 